\title{
Lichens from two inland localities in West Greenland and their climatic preferences
}

Hansen, Eric Steen

Published in:

Botanica Lithuanica

DOI:

10.2478/v10279-012-0003-9

Publication date:

2012

Document version

Publisher's PDF, also known as Version of record

Document license:

CC BY-NC-ND

Citation for published version (APA):

Hansen, E. S. (2012). Lichens from two inland localities in West Greenland and their climatic preferences.

Botanica Lithuanica, 18(1), 19-26. https://doi.org/10.2478/v10279-012-0003-9 


\title{
LICHENS FROM TWO INLAND LOCALITIES IN WEST GREENLAND AND THEIR CLIMATIC PREFERENCES
}

\author{
Eric Steen Hansen
}

Botanical Museum, Natural History Museum of Denmark, University of Copenhagen, Gothersgade 130, DK-1123 Copenhagen K, Denmark; e-mail: erich@snm.ku.dk

\begin{abstract}
Hansen E. S., 2012: Lichens from two inland localities in West Greenland and their climatic preferences [Kerpès iš dviejų vidinių vakarinès Grenlandijos vietovių bei jų klimatinės preferencijos]. - Bot. Lith., 18(1): 19-26.

In total, 143 lichen taxa collected from two inland localities in West Greenland are reported and categorized toward their climatic preferences in Greenland. Eighty three lichen taxa were collected in Eqaluit Ilorliit in the Ameralik Fjord area in 2000 and 120 lichen taxa were collected in Utaap Kuua, east of Sisimiut, in 1998. The two localities share 58 lichen taxa. Almost three fourths of the 143 lichens are more or less equally distributed in continental and oceanic areas in Greenland. About one sixth of the lichens occur most frequently in oceanic areas and more rarely in continental areas, while less than one tenth of the lichens occur frequently in continental areas and more rarely in oceanic areas. The climate of the two localities is low arctic, oceanic. Although they are situated at some distance from the outer coast and close to the continental zone, they are poor in lichens with a mainly continental distribution in Greenland compared to, for example, Kangerlussuaq, which is located in the continental inland region in the southernmost West Greenland.
\end{abstract}

Keywords: West Greenland, climatic preferences, distribution types, ecology, lichenized ascomycetes.

\section{INTRODUCTION}

During the studies on lichen biota in Greenland, K. HANSEN (1971) was the first to pay particular attention to the distribution of the species toward climatic conditions. He defined oceanity-continentality index for the species based on 126 species of macrolichens found in 1962 and 1965. At that time he classified the examined species into four categories: distinctly continental, somewhat continental, climatically indifferent and somewhat oceanic. The author of the present paper (HANSEN, 2010) modified the oceanity-continentality index as follows: distinct continental (not found in the present investigation), somewhat continental, indifferent, somewhat oceanic and distinctly oceanic (found at present). He based the modification on his observations of 200 selected lichens (including microlichens) collected in the southernmost West
Greenland in summer 2008 and K. Hansen's studies on the climatic distribution types.

This paper is the first attempt to compile a list of lichens from two localities in West Greenland. The investigation includes information on the climatic distribution types of lichens and a comparison with previous results obtained during similar studies on lichens from South West Greenland.

\section{STUDY AREA}

The lichens were collected from two inland localities in West Greenland, Eqaluit Ilorliit and Utaap Kuua. Eqaluit Ilorliit $\left(64^{\circ} 09^{\prime} \mathrm{N}, 50^{\circ} 30^{\prime} \mathrm{W}\right)$ is situated in a small bay on the southern coast of the Ameralik Fjord c. $20 \mathrm{~km}$ of its head. The distance to Nuuk, a capital of Greenland is $65 \mathrm{~km}$. The maximum alti- 
tude of the mountains just south of the bay is about $1200 \mathrm{~m}$ a. s. 1. The rocks are largely composed of Amiitsoq gneiss and Nuuk gneiss, and amphibolite occurs abundantly (Lund et al., 2000). The climate is low arctic, oceanic (HANSEN, 1993). The mean annual temperature in July is ca. $7{ }^{\circ} \mathrm{C}$, while in Nuuk it is ca. $8{ }^{\circ} \mathrm{C}$. However, the summer temperatures are somewhat higher and the winter temperatures lower in the inland locality, Eqaluit Ilorliit, than the corresponding temperatures measured in Nuuk. In the same way the annual precipitation is somewhat lower $(756 \mathrm{~mm})$ in the Ameralik locality than that in Nuuk (Lund et al., 2000).

The second locality, Utaap Kuua $\left(67^{\circ} 01^{\prime} \mathrm{N}, 53^{\circ}\right.$ $12^{\prime} \mathrm{W}$ ) is situated in a mountainous area c. $35 \mathrm{~km}$ east of Sisimiut. The maximum altitude of the mountains is comparable to that of the mountains in Eqaluit Ilorliit. Like in the Sisimiut area, the bedrock is mainly composed of Archaean gneiss, which is intruded by younger, more or less basic rocks (HANSEN, 1998). The climate is low arctic and oceanic and comparable to that of Sisimiut, where summer temperature reaches the same level as in Eqaluit Ilorliit, but is somehat lower in winter. The annual precipitation is about $400 \mathrm{~mm}$ in Sisimiut and probably the same or somewhat higher in Utaap Kuua. The mean annual precitation is only $140 \mathrm{~mm}$ in Kangerlussuaq (67 $02^{\prime} \mathrm{N}, 50^{\circ} 40^{\prime} \mathrm{W}$ ).

Mixed dwarf shrub heaths dominated by Betula nana, Ledum groenlandicum and Salix glauca occur abundantly in places with a protected snow cover during winter in Eqaluit Ilorliit (Lund et al., 2000). Ledum palustre and Vaccinium uliginosum are the dominant dwarf shrubs in areas exposed to strong winds and with a thinner snow cover. Both types of dwarf shrub heaths are fairly rich in lichens. Thickets composed of Alnus crispa and Salix glauca occur scattered in the area. A few epiphytic lichens grow on twigs and branches of the shrubs. A steppe vegetation with Artemisia borealis and Carex supina covers some south- and southeast exposed, dry slopes, but it is poorly developed compared to the corresponding vegetation type in Kangerlussuaq (Böcher, 1954, 1959). Different types of saxicolous lichen communities cover the rock faces. Empetrum nigrum is often the dominant species in the mixed dwarf shrub heaths in Utaap Kuua (Lund \& BAY, 1998). They also consist of Betula nana, Ledum groenlandicum, L. palustre, Salix glauca and Vaccinium uliginosum and are generally rich in lichens. Betula nana heaths and fell-fields rich in lichens occur in places exposed to strong winds. Snow-patches dominated by Salix herbacea and rich in lichens are of great importance at higher altitudes. Carex bigelowii is very common and indicates a general dense winter snow cover in Utaap Kuua. The steppe species, Carex supina, is very rare in the area. Like in Eqaluit Ilorliit, saxicolous lichens occur abundantly in Utaap Kuua.

\section{MATERIALS AND METHODS}

The field work was carried out in Utaap Kuua in August 1998 and in Eqaluit Ilorliit in July 2000. Lichens were collected at numerous sample plots of both localities. In Eqaluit Ilorliit, lichens were studied up to $400 \mathrm{~m}$ a. s. 1, whereas in Utaap Kuua, they were investigated up to $500 \mathrm{~m}$ a. $\mathrm{s} .1$.

The substrate preference, the main plant communities in which lichens occur and the stages of thallus ontogeny (fertile or sterile) were noted for the all collected specimens.

The collected material was studied with Zeiss light microscopes. Selected specimens of, for example, Leprocaulon were identified by thin-layer chromatography (TLC). The material is deposited at the Botanical Museum of the University of Copenhagen (C). Nomenclature follows SANTESSON et al. (2004) with some exceptions.

The type of distribution toward oceanity or continentality was estimated for all lichens on the basis of all available information on their total distribution in Greenland.

The oceanity-continentality indices originally defined by K. HANSEN (1971) were somewhat modified as follows: $\mathrm{CCO}$ - somewhat continental lichens occurring most frequently in subcontinental and continental areas and more rarely in oceanic areas; $\mathrm{CO}$ - lichens with almost equally high frequency in continental and oceanic areas; $\mathrm{COO}$ - somewhat oceanic lichens occurring most frequently in oceanic areas and more rarely in continental areas.

The maps and description of Greenland vegetation belts follow Böcher et al. (1968), FEILBERG (1984) and JENSEN (1999). 


\section{RESULTS}

The following list of lichens is based on the author's collection of 235 specimens of lichens, representing 143 taxa. Eighty three taxa were collected in Eqaluit Ilorliit in the Ameralik Fjord area and 120 in Utaap Kuua, east of Sisimiut.

\section{Annotated list OF SPECIES}

Abbreviations: 1 - locality in Eqaluit Ilorliit, 2 locality in Utaap Kuua; ap - specimens with apothecia present, pe - with perithecia, st. - sterile specimens. The climatic preferences of the lichens are stated with the following indices: $\mathrm{CCO}$ - somewhat continental; $\mathrm{CO}$ - indifferent; $\mathrm{COO}$ - somewhat oceanic.

COO Acarospora molybdina (Wahlenb.) A. Massal. - 1. On manured gneissic seashore rocks, together with Caloplaca alcarum, Lecanora contractula, L. straminea and Rhizocarpon grande; ap.

CO A. peliscypha Th. Fr. - 2. On gneissic rock manured by birds; ap.

$\mathrm{CO}$ Alectoria nigricans (Ach.) Nyl. - 2. On soil in dwarf shrub heaths and fell-fields; st.

CO A. ochroleuca (Hoffm.) Massal. - 1, 2. On soil in dwarf shrub heaths and fell-fields; st.

COO Arctocetraria andrejevii (Oxner) Kärnefelt $\&$ A. Thell - 2. On moist soil in dwarf shrub heath; st.

CO Arctoparmelia centrifuga (L.) Hale - 1. On gneissic rock; st.

$\mathrm{CO}$ A. incurva (Pers.) Hale - 2. On gneissic rock; st.

COO Arthrorhaphis citrinella (Ach.) Poelt - 2. On bare mineral soil; ap.

CO Aspicilia berntii A. Nordin, Tibell \& OweLarss.- 1, 2. On gneissic rocks; ap.

CO A. caesiocinerea (Nyl. ex Malbr.) Arnold - 2. On gneissic rock, together with Lecidea tesselata and Rhizocarpon geographicum; ap.

COO Bellemerea alpina (Sommerf.) Clauzade \& $\mathrm{Cl}$. Roux - 2. On gneissic rock; ap.

CO Biatora vernalis (L.) Fr. - 1. On dead mosses; ap.

CO Brodoa oroarctica (Krog) Goward - 1, 2. On gneissic rocks, together with Pseudephebe minuscula; st.
$\mathrm{CO}$ Bryocaulon divergens (Ach.) Kärnefelt -2 . On soil in fell-field, together with Alectoria ochroleuca, Bryoria chalybeiformis and Ochrolechia frigida; st.

CO Bryoria chalybeiformis (L.) Brodo \& D. Hawksw. $-1,2$. On rocks and on soil in dwarf shrub heaths and fell-fields; st.

CO B. nitidula (Th. Fr.) Brodo \& D. Hawksw. - 1 . On soil in dwarf shrub heath; st.

CO Buellia papillata (Sommerf.) Tuck. - 2. On dead mosses, together with Cladonia chlorophaea; st.

COO Caloplaca alcarum Poelt - 1. On manured gneissic seashore rock, together with Lecanora contractula; ap.

CO C. jungermanniae (Vahl) Th. Fr. -1 . On soil rich in humus, together with $C$. tetraspora; ap. C. tetraspora (Nyl.) H. Olivier - 1. On soil rich in humus; ap.

CO Candelariella aurella (Hoffm.) Zahlbr. - 2. On old reindeer antler, together with Lecanora hagenii var. fallax; ap.

CCO C. canadensis H. Magn. - 1, 2. On mineral soil; ap.

CO C. vitellina (Hoffm.) Müll. Arg. - 2. On manured gneissic rock, together with Physcia dubia and Xanthoria candelaria; ap.

CO Cetraria islandica (L.) Ach. - 1, 2. On soil in dwarf shrub heaths; st.

$\mathrm{CO} \quad$ C. nigricans Nyl. -2 . On soil; st.

$\mathrm{CO}$ Cetrariella delisei (Bory ex Schaer.) Kärnefelt \& A. Thell - 1, 2. On soil in moist places in dwarf shrub heaths; ap.

CO Cladonia amaurocraea (Flörke) Schaer. - 1, 2. On soil in dwarf shrub heaths; st.

CO C. arbuscula (Wallr.) Flot. ssp. mitis (Sandst.) Ruoss $-1,2$. On soil in dwarf shrub heaths; st.

COO C. bellidiflora (Ach.) Schaer. - 1, 2. On soil in dwarf shrub heaths; ap.

CO C. borealis $\mathrm{S}$. Stenroos $-1,2$. On soil in dwarf shrub heaths; st.

CO C. carneola (Fr.) Fr. - 1, 2. On soil rich in humus in dwarf shrub heaths, together with $C$. cyanipes; ap.

CO C. cenotea (Ach.) Schaer. - 2. On soil rich in humus in dwarf shrub heaths; st.

$\mathrm{CO}$ C. chlorophaea (Flörke ex Sommerf.) 
Spreng. $-1,2$. On soil rich in humus in dwarf shrub heaths; st.

CO C. coccifera (L.) Willd. - 1, 2. On soil in dwarf shrub heaths; ap.

CO C. cornuta (L.) Hoffm. - 1, 2. On soil rich in humus in dwarf shrub heaths; st.

COO C. crispata (Ach.) Flot. - 2. On soil in dwarf shrub heath; st.

$\mathrm{CO}$ C. cyanipes (Sommerf.) Nyl. - 1, 2. On soil rich in humus in dwarf shrub heaths; st.

COO C. ecmocyna Leight. - 2. On soil in moist places in dwarf shrub heaths; st.

CO C. fimbriata (L.) Fr. - 2. On soil rich in humus in dwarf shrub heath; st.

CO C. gracilis (L.) Willd. - 1, 2. On soil in dwarf shrub heaths; ap.

CO C. macroceras (Delise) Hav. - 1, 2. On soil in dwarf shrub heaths; st.

CO C. macrophylla (Schaer.) Stenh. - 1, 2. On soil rich in humus in dwarf shrub heaths; ap.

$\mathrm{CO}$ C. macrophyllodes Nyl. - 1, 2. On soil in dwarf shrub heaths; st.

COO C. phyllophora Hoffm. - 2. On moist soil rich in humus near fen; st.

CO C. pleurota (Flörke) Schaer. - 1, 2. On soil rich in humus in dwarf shrub heaths; ap.

CCO C. pocillum (Ach.) O. J. Rich. - 1. On soil and mosses in dwarf shrub heaths; st.

CO C. pyxidata (L.) Hoffm. - 1, 2. On soil rich in humus; st.

CO C. rangiferina (L.) F. H. Wigg. - 1, 2. On soil in dwarf shrub heaths; st.

CO C. stellaris (Opiz) Pouzar \& Vezda - 1. On soil in dwarf shrub heath; st.

CO C. stygia (Fr.) Ruoss - 2. On soil in dwarf shrub heaths; st.

COO C. subfurcata (Nyl.) Arnold - 2. On soil in dwarf shrub heath; st.

COO C. sulphurina (Michx.) Fr. - 2. On soil in dwarf shrub heath; st.

COO C. trassii Ahti - 1, 2. On soil in moist places in dwarf shrub heaths; st.

CO C. uncialis (L.) F. H. Wigg. - 1, 2. On soil in dwarf shrub heaths; st.

CO Dimelaena oreina (Ach.) Norman - 2. On gneissic rock; ap.

$\mathrm{CO}$ Euopsis pulvinata (Schaer.) Vain. - 2. On gneissic rock; st.
CO Flavocetraria cucullata (Bellardi) Kärnefelt \& A. Thell - 1, 2. On soil in dwarf shrub heaths; st.

CO F. nivalis (L.) Kärnefelt \& A. Thell - 1, 2. On soil in dwarf shrub heaths and fell-fields; st.

CCO Lasallia pensylvanica (Hoffm.) Llano - 1. On rock; ap.

CO Lecanora atrosulphurea (Wahlenb.) Ach. 2. On manured rock composed of sandstone, together with Melanelia disjuncta, Parmelia sulcata and Xanthoria candelaria, ap.

COO L. contractula Nyl. - 1. On manured gneissic seashore rock; ap.

$\mathrm{CO}$ L. hagenii (Ach.) Ach. var. fallax Hepp -2. On old reindeer antler; ap.

CO L. intricata (Ach.) Ach. - 1, 2. On gneissic rocks, together with L. polytropa; ap.

CO L. polytropa (Ehrh. ex Hoffm.) Rabenh. - 1, 2. On gneissic rocks; ap.

COO L. straminea Wahlenb. ex Ach. - 1. On manured gneissic seashore rock; ap.

COO Lecidea lapicida (Ach.) Ach. var. pantherina Ach. - 2. On gneissic rock, together with Rhizocarpon geographicum; ap.

$\mathrm{CO}$ L. tesselata Flörke - 2. On gneissic rock; ap.

COO Lecidoma demissum (Rutstr.) Gotth. Schneid. \& Hertel-2. On mineral soil; ap.

CO Leprocaulon subalbicans (I. M. Lamb) I. M. Lamb \& A. M. Ward - 1. On mosses.

CCO Lobaria scrobiculata (Scop.) DC. - 2. On manured rock, together with Bryoria chalybeiformis, Parmelia saxatilis and P. sulcata; st.

$\mathrm{CO}$ Lopadium coralloideum (Nyl.) Lynge - 1. On mosses; ap.

CO Melanelia commixta (Nyl.) A. Thell - 2. On siliceous rock; st.

CO M. disjuncta (Erichsen) Essl. - 1, 2. On manured gneissic rocks; st.

CO M. hepatizon (Ach.) A. Thell - 1, 2. On gneissic rocks; ap.

CO Melanohalea infumata (Nyl.) O. Blanco, A. Crespo, Divakar, Essl., D. Hawksw. \& Lumbsch -2 . On manured gneissic rock; st.

COO Nephroma arcticum (L.) Torss. - 2. On soil in dwarf shrub heaths; st.

CCO N. expallidum (Nyl.) Nyl. - 1, 2. On mosses and soil in dwarf shrub heaths; st.

CO N. parile (Ach.) Ach. - 2. On rock; st. 
CO Ochrolechia frigida (Sw.) Lynge - 1, 2. On plant remains, mosses and soil in dwarf shrub heaths; ap.

COO O. tartarea (L.) A. Massal. - 2. On gneissic rock, together with Melanelia hepatizon and Pseudephebe minuscula; st.

CO Ophioparma ventosa (L.) Norman - 2. On gneissic rocks; ap.

CO Orphniospora moriopsis (A. Massal.) D. Hawksw. - 2. On gneissic rocks, together with Melanelia hepatizon and Pseudephebe minuscula; ap.

CO Parmelia omphalodes (L.) Ach. - 1, 2. On rocks; st.

CO P. saxatilis (L.) Ach. - 1, 2. On rocks; st.

CO P. sulcata Taylor - 1, 2. On manured rocks; st.

CCO Parmeliopsis ambigua (Wulfen) Nyl. - 1. On twig; st.

CO Peltigera aphthosa (L.) Willd. - 1. On mosses and twig in dwarf shrub heath; st.

CO P. didactyla (With.) J. R. Laundon - 1, 2. On soil and mosses in dwarf shrub heaths; st.

CCO P. kristinssonii Vitik. - 2. On soil in dwarf shrub heath; st.

CO P. lepidophora (Nyl. ex Vain.) Bitter - 1. On soil rich in humus in dwarf shrub heath; st.

CO P. leucophlebia (Nyl.) Gyeln. - 1. On soil among mosses in dwarf shrub heath; ap.

CO P. malacea (Ach.) Funck - 1, 2. On soil and mosses in dwarf shrub heaths; ap.

CO P. polydactylon (Neck.) Hoffm. - 2. On soil and mosses in dwarf shrub heath; st.

CO P. rufescens (Weiss) Humb. -1 , 2. On soil and mosses in dwarf shrub heaths; ap.

CO P. scabrosa Th. Fr. - 1, 2. On mosses and soil in dwarf shrub heaths; ap.

CO Pertusaria dactylina (Ach.) Nyl. - 1, 2. On mosses in dwarf shrub heaths; st.

CO P. geminipara (Th. Fr.) C. Knight ex Brodo 2. On plant remains; st.

COO P. oculata (Dicks.) Th. Fr. -2 . On plant remains in dwarf shrub heaths; st.

CCO Phaeophyscia sciastra (Ach.) Moberg - 2. On manured rock; st.

CO Physcia caesia (Hoffm.) Fürnr. - 2. On manured siliceous rocks, together with Melanohalea infumata, Physcia dubia, Rhizoplaca melanophthalma, Xanthoria candelaria and $X$. elegans; st.

CO P. dubia (Hoffm.) Lettau - 1, 2. On manured siliceous rocks; st.

CO Physconia detersa (Nyl.) Poelt - 2. On manured rock; st.

CCO P. muscigena (Ach.) Poelt - 2. On mosses and soil; st.

CO Porpidia flavicunda (Ach.) Gowan - 2. On gneissic rock, together with Lecanora polytropa; st.

CO Protoparmelia badia (Hoffm.) Hafellner - 2 . On manured siliceous rock; ap.

CO Pseudephebe minuscula (Nyl. ex Arnold) Brodo \& D. Hawksw. - 1, 2. On siliceous rocks; st.

CO Psora rubiformis (Ach.) Hook. - 2. On mineral soil, together with Candelariella canadensis; ap.

CO Psoroma hypnorum (Vahl) Gray - 1. On mosses in dwarf shrub heaths; ap.

CO P. tenue Henssen var. boreale Henssen - 1, 2. On mosses in dwarf shrub heaths; ap.

CCO Rhizocarpon eupetraeum (Nyl.) Arnold - 1. On gneissic rock, together with Melanelia hepatizon and Rhizocarpon geographicum; ap.

CO R. geminatum Körb. - 2. On manured siliceous rocks; ap.

CO R. geographicum (L.) DC. - 1, 2. On gneissic rocks; ap.

CO R. grande (Flörke) Arnold - 1, 2. On manured gneissic rocks; ap.

CO $R$. inarense (Vain.) Vain. - 2. On gneissic rocks; ap.

CO R. jemtlandicum (Malme) Malme -2 . On gneissic rocks; ap.

CO $R$. rittokense (Hellb.) Th. Fr. -2 . On gneissic rocks; st.

CO Rhizoplaca melanophthalma (DC.) Leuckert $\&$ Poelt $-1,2$. On manured siliceous rocks; ap.

COO Rinodina archaea (Ach.) Arnold - 1, 2. On plant remains; ap.

CO R. turfacea (Wahlenb.) Körb. - 2. On plant remains; ap.

CO Solorina crocea (L.) Ach. - 1, 2. On soil near snow-patches; ap. 
CO Sphaerophorus fragilis (L.) Pers. - 1, 2. On rocks; st.

CO S. globosus (Huds.) Vain. - 1, 2. On soil and mosses in dwarf shrub heaths; st.

CO Stereocaulon alpinum Laurer - 1, 2. On soil in dwarf shrub heaths; ap.

CO S. arenarium (Savicz) I. M. Lamb - 2. On gravelly soil; st.

CO S. capitellatum H. Magn. - 2. On soil rich in humus in dwarf shrub heaths; st.

CO S. glareosum (Savicz) H. Magn. - 2. On gravelly soil in dwarf shrub heaths; st.

CO $S$. paschale (L.) Hoffm. - 1, 2. On soil in dwarf shrub heaths; st.

CO S. vesuvianum Pers. -2 . On siliceous rock rich in iron; st.

CO Thamnolia vermicularis (Sw.) Schaer. var. subuliformis (Ehrh.) Schaer. - 1, 2. On soil in dwarf shrub heaths and fell-fields.

COO Trapeliopsis granulosa (Hoffm.) Lumbsch 2. On peaty soil; st.

CO Umbilicaria arctica (Ach.) Nyl. - 1, 2. On manured rocks; ap.

CCO U. cinereorufescens (Schaer.) Frey - 1, 2. On rocks; st.

CCO U. decussata (Vill.) Zahlbr. - 1, 2. On manured gneissic rocks, together with Xanthoria candelaria; ap.

COO U. deusta (L.) Baumg. - 2. On temporarily moist rock; st.

COO U. havaasii Llano - 2. On rock; st.

$\mathrm{CO} U$. lyngei Schol. -2 . On rock; st.

$\mathrm{CO} U$.nylanderiana (Zahlbr.) H. Magn. - 1, 2. On rocks; ap.

CO U. proboscidea (L.) Schrad. - 2. On gneissic rock; ap.

CO U. virginis Schaer. - 2. On siliceous rock; ap.

CO Xanthoria candelaria (L.) Th. Fr. - 1, 2. On manured gneissic rocks; st.

CO X. elegans (Link) Th. Fr. -1 , 2. On manured siliceous rocks; st.

\section{DISCUSSION}

Almost three fourths of the 143 lichens listed above appear to be more or less equally distributed in continental and oceanic areas and accordingly can be defined as climatically indifferent. These CO-species can be characterized as generally tolerant lichens adapted to a wide range of environmental conditions. About one sixth of the lichens belong to the COOcategory and occur most frequently in oceanic areas and more rarely in continental areas. Some of these lichens are supposed to be threatened by the on-going climate change with increased warming (STENDEL et al., 2008), unless they are able to migrate to habitats, in which their particular requirements, for example, for a sufficient moisture supply, can be fulfilled. Species such as Arctocetraria andrejevii and Cladonia ecmocyna, are often found growing in moist places in dwarf shrub heaths. If these heaths desiccate in the summer period, the lichens might survive near snow-patches, where melt water keeps the soil moist during summer. Only 12 species, less than one tenth of the lichens, have a somewhat continental distribution (CCO). This is somewhat surprising, because the two investigated localities are situated close to the continental zone (JENSEN, 1999). However, species such as Lobaria scrobiculata, Nephroma expallidum and Umbilicaria decussata are typical inland lichens, which also occur commonly in Kangerlussuaq (HANSEN, 2000). Drier climatic conditions during summer will probably accellerate the development of steppe-like vegetation, in particular on sandy soil and loess. Species belonging to the genera Caloplaca, Fulgensia, Leptogium, Phaeorrhiza, Placidium, Psora and Toninia will be able to colonize such steppe-like areas along the border of the continental zone in West Greenland. Close attention needs to be paid to a continuous monitoring of the vegetation in this part of Greenland.

K. Hansen's results from South and South West Greenland differ considerably from the above-mentioned outcome. He concludes that about half of the 126 macrolichens studied by him are more or less indifferent climatically, and that 16 and $22 \%$ of the species have a somewhat continental or oceanic distribution, respectively (HANSEN, 1971). The difference can partly be explained by the fact that the intensified lichenological investigation of numerous poorly known areas in Greenland during the past 40 years has resulted in new knowledge as regards the distribution of Greenland lichens (THOMSON, 1984; 1997; Hansen, 1995; Kristinsson et al., 2010). A number of K. Hansen's COO- and CCO-species be- 
long in fact to the CO-category of climatically indifferent lichens. In the same way his CC-species have to be classified as CCO-species or CO-species. These necessary changes were already made in the investigation on 214 taxa of lichens from five inland and coastal localities in southernmost West Greenland in 2008 (Hansen, 2010). The results from the study are in good accordance with those of the present investigation. Among the 214 lichens two thirds belong to the CO-category, while one fifth of the lichens are COO-species and a little more than one tenth - CCOspecies. Three species belong to a new OO-category consisting of strictly oceanic lichens. The species of the last category were not found in the present investigation.

\section{ACKNOWLEDGEMENTS}

I wish to thank Pipaluk Møller Lund, Linda Odgaard and Christian Bay for valuable help and Pinngortitaleriffik, Grønlands Naturinstitut for logistic support during the field work in 1998 and 2000. Thanks are also due to Lauri Saag for assistance with TLC (Leprocaulon) and Peer Corfixen for technical assistance.

\section{REFERENCES}

Böcher T. W., 1954: Oceanic and Continental Vegetational Complexes in Southwest Greenland. Meddelelser om Grønland, 148: 1-336.

Böcher T. W., 1959: Floristic and ecological studies in Middle West Greenland. - Meddelelser om Grønland, 156: 1-68.

Böcher T. W., Holmen K., Jakobsen K., 1968: The Flora of Greenland. - Copenhagen.

Feilberg J., 1984: A phytogeographical study of South Greenland. Vascular plants. - Meddelelser om Grønland, Bioscience, 15: 1-70.

Hansen E. S., 1993: The lichen flora of coastal and inland areas in the Godthåb Fjord and the Amera- lik Fjord, southwestern Greenland. - Mycotaxon, 48: 249-269.

Hansen E. S., 1995: Greenland Lichens. - Copenhagen.

Hansen E. S., 1998: The lichen flora near Sisimiut, Kangaamiut and Maniitsoq in Central West Greenland. - Herzogia, 13: 199-206.

Hansen E. S., 2000: A contribution to the lichen flora of the Kangerlussuaq area, West Greenland. Cryptogamie, Mycologie, 21: 53-59.

Hansen E. S., 2010: Lichens from five inland and coastal localities in South-West Greenland and their present climatic preferences in Greenland as regards oceanity and continentality. - Bibliotheca Lichenologica, 104: 143-154.

Hansen K., 1971: Lichens in South Greenland, distribution and ecology. - Meddelelser om Grønland, 178: 1-84.

JENSEN D. B., 1999: Grønlands biodiversitet - et landestudie. Teknisk Rapport, 27. - Nuuk.

Kristinsson H., Zhurbenko M., Hansen E. S., 2010: Panarctic checklist of lichens and lichenicolous fungi. Technical Report, 20. - Akureyri.

Lund P. M., BAY C., 1998: Vegetationsundersøgelser $\mathrm{i}$ indlandet ved Kangerlussuaq og nær kysten ved Sisimiut. Teknisk Rapport - Nuuk.

Lund P. M., Hansen E. S., Bay, C., 2000: Græsningsvurdering af dværgbuskheder i Eqaluit ilorliit og Qasiannguit, i Ameralik-fjord, jagtområde Kujataa. - Nuuk.

Santesson R., Moberg R., Nordin A., Tønsberg T., Vitikainen O., 2004: Lichen-forming and lichenicolous fungi of Fennoscandia. - Uppsala.

Stendel M., Christensen J. H. \& Petersen D., 2008: Arctic climate and climate change with a focus on Greenland. - In: Meltofte M., Christensen T. R., Elberling B., Forchhammer M. C. \& RASch M. (eds.), High-arctic ecosystem dynamics in a changing climate: 13-43. - London.

Thomson J. W., 1984: American Arctic lichens. I. The macrolichens. - New York.

Thomson J. W., 1997: American Arctic lichens. II. The microlichens. - Wisconsin. 


\section{KERPĖS IŠ DVIEJŲ VIDINIŲ VAKARINĖS GRENLANDIJOS VIETOVIŲ BEI JŲ KLIMATINĖS PREFERENCIJOS}

\section{Eric Steen Hansen}

\section{Santrauka}

Pateikiami duomenys apie 143 rūšių kerpes iš dviejų vidinių vakarinès Grenlandijos vietovių. Kerpès suklasifikuotos pagal jų klimatines preferencijas Grenlandijoje. 83 kerpių taksonai buvo surinkti $2000 \mathrm{~m}$. Eqaluit Ilorliit vietoveje Ameralik fjordo rajone ir 120 kerpiu taksonu surinkti $1998 \mathrm{~m}$. Utaap Kuua vietoveje, i rytus nuo Sisimiuto. 58 kerpių taksonai aptikti abiejose vietovėse. Beveik trys ketvirčiai iš 143 rūšių kerpių yra daugmaž vienodai paplitusios kontinentinejje ir okeaninèje Grenlandijos dalyse.

Maždaug šeštadalis visų rūšių kerpių yra dažnesnès okeaninèse ir retos kontinentinèse dalyse, ir mažiau nei dešimtadalis dažniau pasitaiko kontinentinèse nei okeaninėse dalyse. Abiejų vietovių klimatas yra okeaninis, arktinių žemumų. Nors abi vietovès yra kiek nutolusios nuo išorinių krantų ir yra arčiau kontinentinès zonos, jose aptinkama nedaug kontinentinio paplitimo kerpiuc, palyginus su, pvz. Kangerlussuaq vietove, esančia vidiniame kontinentiniame regione pietiniame vakarinès Grenlandijos pakraštyje. 